\title{
Tom Stoppard: European Phantom Pain and the Theatre of Faux Biography
}

\author{
Eckart Voigts
}

Citation: Voigts, Eckart. 2021. Tom Stoppard: European Phantom Pain and the Theatre of Faux Biography. Humanities 10: 80. https://doi.org/ 10.3390/h10020080

Received: 7 April 2021

Accepted: 25 May 2021

Published: 1 June 2021

Publisher's Note: MDPI stays neutral with regard to jurisdictional claims in published maps and institutional affiliations.

\section{Copyright: (C) 2021 by the author.} Licensee MDPI, Basel, Switzerland. This article is an open access article distributed under the terms and conditions of the Creative Commons Attribution (CC BY) license (https:// creativecommons.org/licenses/by/ $4.0 /)$.
English and American Studies, TU Braunschweig, 38106 Braunschweig, Germany; e.voigts@tu-braunschweig.de

\begin{abstract}
The paper reads Stoppard's work in the 21st century as further testimony of the gradual politicisation of his work that began in the 1970s under the influence of Czech dissidents, and particularly as a result of his visits to Russia and Prague in 1977. It also provides evidence that Stoppard, since the 1990s, had begun to target emotional responses from his audience to redress the intellectual cool that seems to have shaped his earlier, "absurdist" phase. This turn towards emotionalism, the increasingly elegiac obsession with doubles, unrequited lives, and memory are linked to a set of biographical turning points: the death of his mother and the investigation into his Czech-Jewish family roots, which laid bare the foundations of the Stoppardian art. Examining this kind of "phantom pain" in two of his 21st-century plays, Rock'n'Roll (2006) and Leopoldstadt (2019), the essay argues that Stoppard's work in the 21st century was increasingly coloured by his biography and Jewishness - bringing to the fore an important engagement with European history that helped Stoppard become aware of some blind spots in his attitudes towards Englishness.
\end{abstract}

Keywords: Tom Stoppard; biography; European history; Holocaust/Shoah; Czech Republic; memory; contemporary political drama; Rock'n'Roll (2006); Leopoldstadt (2019)

\section{Introduction}

Tom Stoppard is the most renowned living British playwright. His trademarks since Rosencrantz and Guildenstern Are Dead (1966) have been witty, clever, and intellectual comedies of manners that conjoin the play of ideas with Wildean verbal esprit into philosophical farces, with Jumpers (1972), Travesties (1974), The Real Thing (1983), and Arcadia (1993) the critically acclaimed highlights. His most recent play, Leopoldstadt (2019), has both less linguistic sparkle and less philosophy than his best work. It is, however, testimony of the gradual politicisation of Stoppard's work that began in the 1970s under the influence of Czech dissidents, and particularly as a result of his visits to Russia and Prague in 1977. It also provides evidence that Stoppard, since the 1990s, had begun to target emotional responses from his audience to redress the intellectual cool that seems to have shaped his earlier, "absurdist" phase.

In 2001, in the introduction to her Cambridge Companion to Tom Stoppard, Katherine E. Kelly points out that:

As Stoppard has continued to write, his later work has not only extended his early preoccupation with memory, uncertainty, and ethics but also deepened the sense of human consequence growing from ethical conflict and intellectual doubt. [ . . . In the past ten years [ . . ], Stoppard has overcome the charge of emotional coldness, especially the claim that he failed to represent human love. In slowly dropping his emotional guard, he has imbued his writing with a depth of compassion only hinted at in the earlier work through his consistent appeals to humor. (Kelly 2001, p. 10)

While Kelly's eulogy sees the emotion replacing the humour as an asset, we might at the same time mourn the gradual loss of parody, irony, travesty, and anarchic comic esprit in his work. For a long time, Stoppard has been seen as one of the most conservative 
playwrights in Britain. David Ian Rabey expressed this sentiment in the mid-1980s, praising Stoppard's championing of liberal individualism against state oppressions of various kinds, but ultimately concluding that:

It is true that [Stoppard's] plays aim to demonstrate the practical abuses of the theoretical alternatives to Western capitalist society, thereby latently affirming the latter and ultimately maintaining its conventional image of distance from, and resistance to, the possibilities offered by alternative criteria of social organization. (Rabey 1986, pp. 125-26)

In general, this chapter concurs with Kelly's diagnosis in 2001 and Rabey's analysis nearly forty years ago- that Stoppard has become preoccupied with memory and ethics, has gradually shed his comic exuberance for emotional engagement, and is unable to develop a fully critical attitude towards his home, Britain. Examining two of his 21st-century plays, Rock'n'Roll (2006) and Leopoldstadt, however, we may venture a more balanced view. Stoppard's work in the 21st century was increasingly coloured by his biography and Jewishness-and while the quality of his writing might not always have profited from this turn, it brought to the fore an important engagement with European history that helped Stoppard become aware of some blind spots in his attitudes towards Englishness.

\section{Phantom Memory in a Parallel World: Rock' $^{\prime}$ 'Roll}

In some ways, Stoppard's Professional Foul (1977) and Rock'n'Roll can be seen as precursors to Leopoldstadt, as Stoppard here began to engage with his lost Czech family past. Indeed, Rock' $n$ 'Roll comes close to Stoppard's intention to write an 'autobiography in a parallel world', and Hermione Lee (2020, p. 13) has listed the autobiographical elements that can be found in the play: The character Jan, just like Leo in Leopoldstadt, is a thinly veiled version of Stoppard-Jan's name in the first draft was Tomas, and was a Jew born in Zlín, who left Czechoslovakia before the Germans came, but-and here the real and the fantasy biography diverge-returned to communist Prague. It is here that we encounter Stoppard's writing as assuaging a phantom pain: in his plays, he creates characters that vicariously live through the painful experience of 20th century mid-European politics shaped by Nazi persecution and communism - the kind of persecution and strife that Stoppard himself escaped by virtue of his mother's refuge in India and Britain. As in a phantom pain, Stoppard has no direct physical experience of the communist regime or the Shoah, but his plays create a phantom memory-here it is Jan for Tom/Tomas. In this sense, Stoppard's Rock'n'Roll and Leopoldstadt are faux biographies: they dramatise a recollected past that Stoppard himself has never experienced. Most importantly, Jan is a creature of nostalgic wishful thinking who articulates Stoppard's fantasy of a successful and harmonious amalgamation of Czech refugee culture and the welcoming cultural arms of a benign England, fed by his memories of 1947:

I love England. I would like to live forever in my last English schoolboy summer.

[ ... ] my mother knew all the songs, she baked svetskove buchty for all my friends,

and sang 'We'll Meet Again' in a terrible accent over the washtub. I was happy.

(Stoppard 2006, p. 38)

In the play, Jan returns to Prague; in reality, Stoppard remained in England to nostalgically revisit his happy youth, the basis of an assimilated acceptance in England that paved his way upward in the cultural hierarchy towards knighthood and royal dinner parties. In the face of increasingly restrictive refugee policies since the 1980s (see Turner 2015), ${ }^{1}$ the self-satisfied nostalgia for an idyll of Western freedom seems hard to swallow, and a more ambivalent attitude towards England seems in order. As Mulvey (2010), among others, has shown, long before the Tory government crackdown on immigration, spurred on by a right wing press, refugees in Britain (as elsewhere in Europe) have been affected

1 The actual number of refugees and asylum seekers in the UK is significantly smaller than elsewhere in Europe. For up-to-date statistics, see The Migration Observatory at the University of Oxford (https://migrationobservatory.ox.ac.uk/resources/briefings/migration-to-the-uk-asylum/) accessed on 29 May 2021. 
by hostile policies and discourse. Gabrielatos and Baker $(2008$, p. 30) found that RASIM (refugees, asylum seekers, immigrants and migrants) were subjected to "blatant negative bias", particularly in the British tabloid press.

Rock'n'Roll covers a span from the so-called "Prague Spring" of 1968 to the "Velvet Revolution" of 1989. Jan is a philosophy student who spends the late 1960s in Cambridge, working on a PhD with his supervisor Max, who is a loyal Marxist. ${ }^{2}$ Here, Stoppard revisits the ground that had inspired his 1977 play, Professional Foul, which criticised the rather too sanguine position of Western Marxists vis-à-vis the Stalinist communism of the Cold War period. Max is a collectivist and materialist (both in terms of his politics and in his take on human consciousness and inspiration as "neuron-firings whizzing about the cortex" (Stoppard 2006, p. 58) and embodies the "Champagne socialism" that Stoppard decried. Granted, he is less of a satirical character than Lenin in Travesties, but Stoppard clearly sides with the alternative view represented by Jan and by Max's wife Eleanor-both Eleanor and her daughter Esme were played by Stoppard's then lover Sinead Cusack. Dying from cancer, Eleanor articulates a powerful alternative to the materialist view of humanity when she says of her cancer-ridden body: "I am not my body. My body is nothing without me, that's the truth of it" (Stoppard 2006, p. 62). Art, ideas, and emotion are the components Stoppard enlists to counter the Marxist-materialist views. Over the course of the play, the friendship of Max and Jan survives the ideological disagreement between them. When Max's new girlfriend Lenka challenges Jan, however, telling him that the Czech Republic should not follow the English example, as in England they have started to apologise for "history", "good manners", and "difference" (Stoppard 2006, p. 113), this seems quite muddled as political analysis. Ondřej Pilný has made the more general point that Stoppard overstates the power of rock music to bring down political regimes. ${ }^{3}$

The political role of aesthetics is examined in a number of examples in Rock'n'Roll, chief among them the titular rock music. Originally planned as a fragmentary piece inspired by the fragments from Sappho's verses, the scenes are punctuated by recognisable rock songs of western provenance (Bob Dylan, Pink Floyd, Beach Boys, U2, Guns N' Roses) and the Prague band The Plastic People of the Universe. ${ }^{4}$ Indeed this band is seen as a major challenge to the communist political power in spite of their apolitical attitude. As is usual in a Stoppard play, the inelasticity of the oppressive totalitarian regime is played out in their response to the aesthetic freedom of writers and musicians, and the point is driven home that-in spite of its rejection of political activism—unfettered, incontrollable, and anarchic art can play a major part in bringing down oppressive and ossified regimes. The regime forces Jan to compromise, symbolised by making him eat a biscuit he does not really like. They spy on him, put him in prison, make him work in a bakery, and smash his beloved record collection-echoing the fate of dissidents such as Václav Havel or Milan Kundera. As Jan, who is punished for attending a Plastic People concert, explains to his friend Ferdinand, who asks him to sign a petition on behalf of the Charter 77 dissidents, it is precisely the apolitical stance, the opting out of political positions, that makes the Plastic People so dangerous to the regime, as they refuse the role of antagonist assigned to them by the ruling party: “The Plastics don't care at all. They're unbribable. They're not heretics, they're pagans ..." " (Stoppard 2006, p. 37).

While Sappho's poetry counters materialism, the God Pan, associated with music, excess, and sexuality, links The Plastic People of the Universe with Pink Floyd's founding member Syd Barrett, the mastermind behind their first album "A Piper at the Gates of Dawn", and major inspiration for the band's subsequent catalogue. He features prominently in the play, appearing in the initial scene indeed as the God Pan, or "The Piper" to

2 Max is somewhat modeled on Arnold Kettle and Eric Hobsbawm (see Lee 2020, p. 732), and Hermione Lee (2020, p. 740) speculates that Max's fierce ideology and Jan's irony may represent discussions between Pinter and Stoppard.

3 "Stoppard seems to be intent on demonstrating how the power of rock music may play a momentous role in overthrowing an oppressive regime like that of communist Czechoslovakia, which is a claim that a conscientious historian would find hard to substantiate fully, regardless of the undeniable importance of the support of dissidents for The Plastic People of the Universe" (Pilný 2012, p. 71).

4 Pilný (2012, p. 68) has shown in detail how the song lyrics work thematically as leitmotif and counterpoint to the action. 
the character Esme, singing his hypnotic "Goldenhair" (based on a poem from Chamber Music by James Joyce). Later, now a balding shadow of his former self, Barrett meets Esme's daughter Alice in a Cambridge shop and mistakes her for Esme. Esme tells the story of how she was present at Barrett's final concert, which "was terrible and somehow great" (Stoppard 2006, p. 78) and identifies Barrett as Pan, the Piper. The fate of Barrett is, therefore, another key inspiration for Rock'n'Roll, a wild-haired maverick performer and thorn in the flesh of the Western music business, who is failed by the corporate machinery and whose self-destructive lifestyle drives him out of the band until he finally ends up "an old baldy with his groceries on a bike" (Lee 2020, p. 739) and an embarrassment to his former bandmates.

It is easy to see Barrett in Stoppard's play as the Western equivalent of the Eastern Bloc Plastic People: Rock'n'roll helps bring down the oppressive regime in Prague, but no-one seems to care for the band's aesthetic qualities ("Foreign journalists never mention the music," Jan complains, Stoppard 2006, p. 73). Its role in western capitalism is vastly different, but similarly anti-aesthetic, as commercial success eclipses artistic quality. As represented by "Pan" Barrett, excessive art deteriorates in the West and falters in the face of hedonistic freedom, brought down cruelly by a sensationalist press (see Stoppard 2006, p. 111). Barrett features as an emblem of the enchanting outsider artist of the late 1960s, subsequently crushed by a capitalist culture industry. Both via Barrett and the Marxist intelligentsia Stoppard's play engages critically with England.

The play ends with happy (re-)unifications: Max and his new girlfriend Lenka, Esme and Cambridge (via her daughter Alice), Lenka with her pupil Deirdre and classic learning. The major happy ending, though, is between Jan and Esme, who agrees to accompany him to the Rolling Stones concert in Prague. There, she requires unlimited sex from Jan in a 20-years delayed hedonistic paradise, drowned in the music from the famous Stones concert in August 1990: an unqualified triumph to Pan, the Pagans, and the power of sex and drugs and rock' $n$ 'roll-in view of the subsequent corruption and the crippling of the welfare state in the Czech Republic in an eastern version of Thatcherite liberalism, this was an ending that rang hollow in many Czech ears. By contrast, the ending of Leopoldstadt suggests a less sanguine perspective on history.

The Royal Court premiere of Rock'n'Roll was a high-society affair, with some leftwing criticism by William Gaskill and possibly Caryl Churchill, as Hermione Lee (2020, pp. 747-48) reported. Guests included Havel, Mick Jagger, and members of both Pink Floyd and the Plastic People. It seems bitterly ironic that while Rock'n'Roll had its West End run in the summer of 2006, Roger "Syd" Barrett died at sixty, oblivious to the fact that an actor embodied him as the God Pan, a symbol of the powers of apolitical excess on the bourgeois stage of the Royal Court, with Deirdre quoting from Plutarch: "Great Pan is dead!" (Stoppard 2006, p. 117).

\section{Family Album: Leopoldstadt}

In Leopoldstadt, Stoppard went further back into his Czech family history. He wrote his "Jewish play" from 2018 to 2019, at the age of 81/82; it opened in the West End at Wyndham's Theatre in February 2020, but its run was cut short by the COVID pandemic. In spite of some criticism, it generally received favourable reviews and garnered two Olivier awards (Best New Play, Adrian Scarborough (Hermann) for Best Supporting Actor). I shall argue that, in spite of the shortcomings correctly pointed out by some critics, the play is important. At a crucial moment in English history-the imminent Brexit secession from British-European identity, it articulates the fundamental importance of the UK's core European-ness as one of the key lessons of 20th-century history. Seeing the initial salon splendor of the fashionable apartment in the grand Vienna Ringstrasse, where the assimilated upper-class Jewish family of Hermann Merz lives, the rich viewers who can afford a West End ticket these days are reminded that for all their comfortable, debonair cosmopolitanism, they might be under threat at any time from new waves of fascism, antisemitism, or other reactionary and racist trends: Even an enlightened western 
democracy might be jolted into the Dark Ages of authoritarianism and xenophobia. While it is surely biographically a central exploration of Stoppard's identity, it also provides a wider remit to this panoramic European history. Stoppard's play spans almost an entire century and tells its story structurally as a narrative of loss. The first, very long scene was tinted in sepia colours in Patrick Marber's production and felt like a tableau vivant of a large family portrait of an elegant bourgeois Vienna family. In fact, "Family Album" was the working title for Leopoldstadt. As the play progresses the number of family members and the homeliness and urban sophistication of the family spaces keep being reduced and diminished while the light becomes starker.

Leopoldstadt is the final stepping stone in Stoppard's way towards an increasing engagement with his own biography, and in particular his Jewish roots. Characteristically, he displaces the setting from Prague to Vienna, in order to fill the stage with references to this intellectually, politically, and artistically pivotal place of the inter-war years in the 20th century. In line with his usual modus operandi, he crams in a plethora of studiously researched material, but this time with a more explicit biographical engagement with his own family history than in previous plays. As Hermione Lee's biography sketches in detail, he started writing the play in 2018 under the influence of extensive reading on the Holocaust, Vienna, and Jewish family histories. The first impetus may have come from seeing Daniel Kehlmann's play Ghosts in Princeton (2015). Kehlmann, a household name on the German literary scene since his bestselling Measuring the World (2006), sketches the lives of mathematicians Gödel ${ }^{5}$ and Einstein, and Stoppard had frequent conversations with the Austro-German writer while he wrote Leopoldstadt. In some ways, the rediscovery of his continental family history seems to have mitigated his previous uncritically enthusiastic embrace of Englishness.

Two biographies—by Ira Nadel and, more recently, Hermione Lee—-have explored Stoppard's life. He was born Tomas Sträussler on 3 July 1937, in Zlín, in former Czechoslovakia, to the physician Eugene Sträussler and his wife Marta. Escaping from the encroaching Nazi regime, the family moved to Singapore in 1939. Here, they had to escape again, this time from the Japanese invasion, and while his father was killed in Singapore, Stoppard, his brother, and his mother fled, first to India, and then, his mother having married the British officer Kenneth Stoppard, relocated to England.

Stoppard was always aware of his "outsider" roots. In 1977, à propos a profile penned by Kenneth Tynan that pointed out the gaps and mysteries in Stoppard's life before he emigrated to England with his mother and brothers, he encouraged his mother to write up the family histories (without much response, see Lee 2020, p. 344). It seems, however, he only learned in 1993, at the age of 56, just how Jewish he was, having been told that all of his four grandparents were Jewish.

His mother, once again, made little of her Jewish ancestry, and it is true that Stoppard never practised Judaism and knew very little about Jewishness (nor his Czech upbringing) until very late in his life. He was raised wholly as a naturalised Englishman from setting foot on the British Isles at the age of eight, so that few identity traits seemed to remain from his European émigré biography. Thus, both Stoppard's family and the English milieu in which he was brought up maintained a silence about his Czech-Jewish ancestry, so that (probably unlike his mother Marta) he did not even have to disavow his background.

As is explored in more detail in the recent Companion to British-Jewish Theatre, the immediate post-Second World War generation of British-Jewish theatre artists were cagey about their identity. Harold Pinter, when asked, said he considered himself a Jew who writes rather than a Jewish writer (in Billington 2007, p. 189), maintaining that he did not tackle overtly or explicitly Jewish themes and representations. Like Stoppard, both Harold Pinter and Mike Leigh turned to address their Jewishness more directly in their later years. 
In Stoppard's generation, Jewishness may have been a part of a playwright's identity, but it very rarely bubbled to the surface of their writing and would have to be detected as implicit subtext. Even the most outspoken Jewish playwright of this generation, Arnold Wesker, easily blended into the broader discontentment of disillusioned utopias articulated by John Osborne and the angry young men, so that Sally Whyte concludes: "Although Wesker is an open and partisan Jew, very little of this is evident in the bulk of his work" (Whyte 2003, p. 1149). As in the case of the South African Jew Ronald Harwood, who anglicised his name from Horwitz after having been told by a teacher at the Royal Academy of Dramatic Arts that his name was too foreign and too Jewish for a British actor (Walker 2006), Stoppard's English name eased his transition to become, in many ways, a quintessentially English playwright.

Stoppard's 2019 Leopoldstadt, therefore, was frequently seen as a "coming out" (when in fact the discovery of his Jewishness precedes the play by many years). A fascinating parallel case (albeit in a very different cultural and political milieu) is Mike Leigh's Two Thousand Years (2006). In his preface, Leigh casts his British-Jewish identity in words that also apply to Stoppard:

Here's my Jewish play. I've been threatening to do it for years, but I haven't felt ready until now, when I'm well into my sixties. ... Those of us who escaped from our Jewish background have usually spent most of our adult lives keeping quiet about our Jewishness, at least. This isn't about being ashamed of one's identity, it's rather about being perceived as something you're actually not, or being cast as a stereotype role that isn't your true self. ... Two Thousand Years is both a Jewish play, and a play for and about everybody. (Leigh 2006, pp. v, vii)

In the case of Stoppard, however, the escape from his Jewish background was performed by his mother. Stoppard learned of his Jewish ancestry when he was nearing sixty, but it took more than 25 years for him to fully address, in fictional terms, his Czech-Jewish past. He is, at the same time, a quintessentially English playwright and a Jewish playwright all too aware of being stereotyped in the British perception. In what follows, I will briefly sketch Stoppard's journey from his invisible Jewishness to a more open acknowledgement of his Czech-Jewish roots.

Three precisely datable events, meeting Sarka Gauglitz at the National Theatre on 11 March 1993, the encounter with Alexandr Rosa, grandson of Stoppard's aunt Berta, in late November 1994 in Prague, and the death of his mother, born Marta Beckova (married as Marta Sträussler, and re-married as "Bobby" Stoppard) on 11 October 1996, prompted Stoppard's discovery of his own Jewishness. Sarka Gauglitz, from Hanover, was the granddaughter of Marta Beckova's sister Wilma. She met Stoppard and his mother, Marta, drew a family tree for him at the restaurant of the National Theatre and informed him that he was $100 \%$ Jewish. The following conversation on Stoppard's almost vanished Czech-Jewish family made it almost verbatim to the moving final scene of Leopoldstadt:

"What happened to Wilma?"

"She died in Auschwitz".

"Berta?"

"Auschwitz".

"Anny?"

"She died in a different camp. I don't know where." (in Lee 2020, p. 581)

Alexandr Rosa waited for Stoppard in the lobby of the Prague Hotel Atrium in November 1994 to show him a family album and tell him how his father, the son of Marta/"Bobby"'s aunt, survived the Shoah by being given up to complete strangers. In her biography, Hermione Lee points out that Marta tried to shroud her Jewish ancestry:

All [ ... ] Jewish-Czech survivors of the Beck family [ ... ] had parents who had not wanted them to learn about the past and who preferred silence, parents who had survived when others had perished. (Lee 2020, p. 584) 
The awareness of his Czech roots, however, and his persistent interest in European history frequently joined into a highly critical attitude towards communist totalitarianism and ostensibly leftist literature engagée. His long-standing friendship with Václav Havel had already paved the way for his later plays, in particular Rock' $n^{\prime}$ Roll and Leopoldstadt, which gave his work a new autobiographical dimension.

Stoppard's new-found Jewishness permeates Ira Nadel's biography and, with assistance of more and better source material, also figures prominently in Hermione Lee's authorised biography. Stoppard visited his birthplace Zlín for the first time in 1999 and wrote the well-known essay "On Turning Out to Be Jewish", recalling a meeting with Zaria Albertova, who showed him a scar stitched by his father: "I have nothing that came from my father, nothing he owned or touched, but here is his trace, a small scar" (Lee 2020, p. 638). While Stoppard's biography has also fed into his work (such as marital strife into The Real Thing), his trademark has always been the dazzling rhetoric and linguistic inventiveness that was fed by a plethora of intellectual, philosophical, and artistic obsessions, so much so that Stoppard increasingly worried whether his younger audiences were still familiar enough with the multifarious cultural contexts of his plays.

In the case of Leopoldstadt, the critics were quick to point out that the Stoppardian wit was largely missing from the play. "What is initially striking about Leopoldstadt is its lack of hallmarks such as the linguistic play and pirandellian tricks that have laced Stoppard's body of work," remarked Arifa Akbar (2020) in the Guardian. Calling it an "elegiac epic", the review missed any round, dynamic character portrait in the cast of 40 . Ben Brantley in the New York Times called it "his most conventional drama by far" and noted that the play "is mostly devoid of the intellectual jeux d'esprit that have been its creator's signature" (Brantley 2020). In a perceptive piece of criticism, Toby Lichtig in the Times Literary Supplement (Lichtig 2020) invokes Helen Epstein in Children of the Holocaust (1979) and argues that Leopoldstadt offers a Jewish family tree reduced to a stump by the Shoah.

First and foremost, Leopoldstadt is a faux autobiography and a Holocaust play. The Shoah is a recurrent and relatively well-researched force field in contemporary BritishJewish playwriting (White 1999; Plunka 2009; Behlau-Dengler 2011) and its centrality in contemporary Jewish consciousness is beyond doubt. Leopoldstadt answers in familiar ways the crucial question of how British-Jewish playwrights could possibly respond to the challenges of representability posed by the enormity of the Holocaust. Are images of the Shoah exploitative, idolatrous? Is art after Auschwitz, as Adorno claimed, "barbaric", and "unspeakable" in language and literature (George Steiner, see Plunka 2009, pp. 11, 14)? Stoppard's Leopoldstadt in January 2021 follows many predecessors in positioning English spectators as non-present witnesses to the horrors of the Shoah. Plays that have dealt with these issues, from the early 1990s to the first decade of the new millennium after 9/11, include such prominent cases as Diane Samuels' Kindertransport (1993) and Harold Pinter's Ashes to Ashes (1996).

If we compare Pinter's allusive, and elusive, two-hander Ashes to Ashes with Stoppard's Leopoldstadt, a memory play crammed with Stoppard's extensive reading into Viennese history, the differences in approach become evident-from Pinter's modernist ambiguity to the mimetic realism jam-packed with Stoppard's reading in the epic display of Leopoldstadt. We are certainly a far cry from Stoppard's toying with absurdism in After Magritte or the philosophical metadrama of Rosencrantz and Guildenstern are Dead or The Real Thing. In 1975, á propos Travesties, Stoppard has said of his old dramatic self: "I think I enlist comedy to serious purpose. I wonder if I don't trivialise something serious." (in Gussow 1995, p. 30). When he continues that "I think there will come a time when I will not want to write in comic terms" (Gussow 1995, p. 30), the elegiac epic Leopoldstadt finally seems to make good on this promise. 
While memory narratives of survivors are the format of choice in many plays that tackle the Shoah, ${ }^{6}$ other plays, such as Samuels' influential Kindertransport, arguably the most successful Holocaust play by a British-Jewish playwright, focuses on the phantom pain of Jewish escapees who fled from the Shoah to the British Isles. Leopoldstadt finally exposes Stoppard's phantom pain, partaking in the joint endeavour of Kindertransport and other British-Jewish plays that engage with the Shoah to fill a blind spot in British collective memory. Whereas Julia Pascal's play Theresa directly attacks the shortcomings of British policies with respect to the Shoah, ${ }^{7}$ both Stoppard and Samuels are preoccupied with the destruction and traumatisation of private worlds. While his play is lacking the interventionist criticism of British policies, it instead focuses of the survivor's guilt of British-Jewish characters confronted with their family history.

Many decisions about Leopoldstadt suggest a deliberate toning down of the historical and aesthetic travesties that dominated Stoppard plays such as Travesties, The Invention of Love, or Arcadia. Travesties may have been the parody of a memory play, as Brian Richardson (2001) claims, but Leopoldstadt has almost completely shed the parodic distancing devices of humour and parody. Historical characters such as Sigmund Freud, Theodor Herzl, Gustav Klimt, Gustav Mahler, and Arthur Schnitzler ${ }^{8}$ emerge in discussions and serve to embody the philosophical and aesthetic bourgeois climate of inter-war Vienna. The infamous faculty painting controversy around Klimt's Die Philosophie in 1901 illustrates the precarious role of Jewish artists within the latent antisemitism festering among the Viennese upper class. This is best embodied by Vienna's antisemitic mayor Karl Lueger who dismissed Klimt's paintings as offensive. The name of "der schöne Karl" decorated the Ringstrasse until 2012, while the Karl-Lueger-Platz exists to this day. The portrait of Gretl was inspired by the portrait of Szerena Lederer, also painted in 1899 by Klimt. Lederer's family helped Klimt repay the advance he received for the faculty paintings.

The Riemann hypothesis - an obsession of Hermann's brother-in-law Ludwig—as well as the mathematics of the Cat's Cradle game are reminiscent of Fermat's Theorem and grouse populations in Arcadia. Here, however, mathematics is merely an objective correlative to anything pure, logical, and untainted by the vagaries of politics and human strife. Ludwig argues that "a number theorist, however great, is innocent of usefulness" (Stoppard 2020, p. 20). All in all, this reads like a recapitulation of the inconsequential pursuits Tom Stoppard celebrated all his life—fiction, mathematics, philosophy, art—against the normative power of de facto realities- "Jewish" identity, racism, xenophobia, the Nazi rise to power, resistance to immigration, the Shoah, and, in general, human beings as pawns in political power games.

The family in Leopoldstadt is a blend of the assimilated wealthy Middle-European Jewry that Stoppard read about, which obviously resonates with his Czech family:

They have left the ghetto behind them. They don't live in Leopoldstadt any more, but on the Ringstrasse. They have converted and intermarried. They are Jewish and Protestant and Catholic. Their children are baptised and circumcised ('in the same week'). They celebrate Christmas and Seder. They are part of the class that run the city and the culture [ ... ]. (Lee 2020, p. 849; emphasis in original)

In fact, the title of the play refers as much to Vienna's second "Bezirk", the traditionally Jewish Leopoldstadt from which the family has escaped and to which it has to return, as to

6 Antony Sher's Primo (National Theatre 2004), an adaptation of Primo Levi's Auschwitz memoir If This Is a Man, is exemplary in its spare aesthetics and deliberate avoidance of directly illustrating an unrepresentable horror. Sher is aided by the matter-of-fact sobriety of horrific detail in the Italian chemist's account. Similar memory narratives include one-handers such as Martin Sherman's Rose (National Theatre 1999) and Gail Louw's multi-award-winning Blonde Poison (2011).

7 Theresa explores the fate of Theresia Steiner, who was deported from Guernsey in 1942 and subsequently murdered in Auschwitz, revealing British collaboration with the Nazis on the Channel Islands. The accusation of British collaboration combined with latent antisemitism led to Theresa being banned in Guernsey, where only a radio broadcast of the play could be heard (Lassner 2014, p. 175). The play was largely ostracized in the British theatre scene, arguably because it challenged the "distinctiveness of the British character in contrast to those who fell victim to Hitler" (Luckhurst 2000, p. 147).

8 The biography of Hermione Lee is a treasure trove for these references: the names of the army officers, Theo and Fritz, are taken from Schnitzler's Dalliance, and his Reigen/La Ronde plays a part in the plot (Lee 2020, p. 851)—Stoppard had previously adapted both plays. 
the name of Leo-who has shed his Viennese Leopold for the Leonard of his British identity. The covering up of his Jewish name traces is challenged by the survivor Nathan: "By the way, Leo, what is it with Leonard? Your name was Leopold. Too Jewish?" (Stoppard 2020, p. 92). The fact that Leo's new surname, given by his step-father Percy (like Stoppard's own by his stepfather Kenneth), is Chamberlain immediately invokes the British appeasement stance towards Hitler in the early 1930s. ${ }^{9}$

The most obvious critique of Western countries comes in this assimilated AngloJewish character of Leo and the play's discussion of the Evian conference in 1938. Here, Western countries failed to accept more refugees and maintained severe quotas for Jewish immigration, playing into the hands of Nazi antisemitism and, in many ways, sealing the fate of families like the one whose story is told in Leopoldstadt. Again, however, Stoppard uses the detour of Nazi oppression to make a rather oblique case against anti-refugee sentiment in contemporary Britain.

The element of survivor's guilt is blatantly evident in Leo, the British-Jewish character in Leopoldstadt. The pivotal confrontation of Auschwitz survivor Nathan with the Stoppard alter-ego Leo and the American-Jewish Rosa (possibly named after Alexandr Rosa) occurs in the final scene 9 of the play. The strongest and most adequate representation of the horrors in the Shoah occurs here, at the very end of the play, when Stoppard's strategy of suggesting loss by gradually diminishing both setting and language, which I discuss below in more detail, reaches its climax. Quoting almost verbatim the words Alexandr Rosa told Stoppard in Prague (see above), the adequately named Rosa responds monotonously to Leo's ignorant questions about the fate of family members with the place name most iconic for the Holocaust. In a long incantation of family members killed in the first half of the 20th century, most of them in the Shoah, the pairing of names and this place-name, a metonymy of murder, is enough for a quietly allusive representation of unspeakable suffering:

Leo: Mimi

Rosa: Auschwitz

Leo: Bella

Rosa: Auschwitz

Leo: Hermine

Rosa: Auschwitz.

Leo: Heini

Rosa: Auschwitz. (Stoppard 2020, p. 105)

Introduced as a "clean young Englishman" by Nathan (2020, p. 94), Leo is in many ways Stoppard himself: a writer of "funny books", a refugee from a family that disavowed its Jewish past, whose now deceased mother re-married an Englishman. He confesses at the end of the play that he knew he was Jewish, but in England "it wasn't something you had to know, or something people had to know about other people" (Stoppard 2020, p. 96). Stoppard gives Leo words to describe his Englishness that he himself has used in non-fictional contexts:

My mother didn't want me to go to school with a German name. I was Leonard Chamberlain from when I was eight. She never talked about home and family. She didn't want me to have Jewish relatives in case Hitler won. She wanted me to be an English boy. I didn't mind. [ ... ] We were the top country! I loved being English. I didn't know I had an accent until I lost it. [ . . . ]

I'm proud to be English, to belong to a nation, which is looked up for ... you know ... fair play and parliament and freedom of everything, asylum for exiles and refugees, the Royal Navy, the royal family ... [ . . . ] Oh, I forgot Shakespeare. [ ... ] really, a charmed life [ ... ]. (Stoppard 2020, pp. 94/97)

9 The more immediate source for the name is Stoppard's long-standing PA and friend Jacky Chamberlain who—as an in-joke—appears in many of his plays (see Lee 2020, p. 262). 
The "charmed life" is a recurring phrase in Stoppard's self-presentation (see Lee 2020, pp. 842-45) and the ironic glibness Stoppard gives Leo's self-image signals the dissociation from his former self that began with Stoppard's exploration of his Jewish-Czech roots. Obviously, Nathan doubts Leo's Jewishness in spite of the fact that he is more ethnically Jewish than either himself or Rosa-both of whom seem to better embody Jewish 20thcentury experience and attitudes. His main fault is ignorance-he is neither aware of Jewish suicides after the Anschluss, nor of Jewish suicides out of survivor's guilt after the war (Stoppard 2020, p. 96). Nathan asks him about his father, and Leo takes the question to be about his adoptive father Percy, not his biological father Aaron Rosenbaum, a revolutionary socialist killed during the general strike of 1934. When Rosa recalls how she forgot where she hid the affikomen (Gk., "desert", matzah broken during Passover Seder)—prompting a brief flashback to scene six-Leo goes completely blank. This is significant because Seder is the occasion to retell Jewish history and therefore a crucial articulation of Leopoldstadt as a memory play. The duty to retell the story keeps the narrative alive-a ritual antidote to the ever-threatening loss of memory articulated by the central character Grandma Merz in the first scene. Looking at a couple waving goodbye from a train in the family photo album, she realises that visual evidence always needs an anchor: "It's a like a second death to lose your name in a family album" (Stoppard 2020, p. 19), and here Stoppard's original title Family Album is referenced. Finally, Leo, in his request for the fate of family members killed mostly in the Shoah, seeks to retrieve names and prevent this second death in a case of belated Trauerarbeit ("grief work", Sigmund Freud's term). The passage invokes Roland Barthes who has, just like Susan Sontag before him, associated photography with death. For Barthes, the photograph is a trace, a corpse or spectre, which resonates with ideas formed á propos a photo of his dead mother: "it is the living image of a dead thing. [ ... ] The effect it produces upon me is not to restore what has been abolished (by time, by distance) but to attest that what I see has indeed existed" (Barthes [1980] 1981, pp. 79, 82).

While the family parlour is the only setting in Leopoldstadt, the temporal organisation unfolds along four stages, each representing a crucial moment in the fading of Jewish life and the attempts to hang on to diminishing memories. The first scene has the entire company on stage, celebrating an extended, fully assimilated Jewish-Christian Christmas at the beginning of the 20th century, in December 1899. This phase is the longest, most populated, and warmly exuberant. Gradually, the Jewish patriarch Hermann recognises that assimilation is a chimera through a story of marital infidelity. Having been insulted by the Austrian "goyish" officer Fritz, who also had an affair with his wife Gretl, he concludes: "God forgive me that I should dine with men like you and consider myself raised up in the world!" (Stoppard 2020, p. 39). The following celebration of Seder (scene six) is itself a memory occasion, reminding the Jews of the expulsion from Egypt for the beginning of Passover.

Scene seven introduces the next, second stage, 1924, and the apartment is not yet visibly altered for Nathan's circumcision. The effects of the First World War, however, have diminished the wealth and status of the Merz family on the brink of a global economic crisis and antisemitism is on the rise, represented here by the nationalist-voting banker Otto.

As the scenes get shorter, so the apartment appears diminished, as wealthy objects and servants disappear in the next stage, scene eight, set in 1938. Here, a "Civilian" Nazi appears, who confiscates the entire space and marks the expulsion of the Jewish family: "You're not at home now." The scene expresses the importance of an intact public sphere and free journalism for the preservation of democratic structures by throwing the totalitarian disregard for the British journalist present (Percy, Leo's father) into sharp relief- "Do you think I give a shit about English journalists? I can wipe my arse with your accreditation any time I like" (Stoppard 2020, p. 77). The persistent effects of the past on the present-an overarching theme in Stoppard's work-is embodied by the scar Leo receives while collecting the shreds of a cup broken by Ludwig in fear of the Civilian, clearly inspired by the scar stitched by his father that Stoppard saw when he visited Zlín in 1999. The missing portrait of Gretl is another objective correlative of broken continuity, of 
disrupted and recovered memory; ultimately, it will be restituted to the American Rosa in 1955. Thus, the Beutekunst discussion also finds its way into Leopoldstadt, invoking the looting of Louis Rothschild's collection after the Anschluss, or the fate of the "Aryanised" Lederer family collection.

Cut to the final station in the temporal structure, 1955, and the aftermath of the Holocaust. The American émigré Rosa has bought the apartment back and decided to stay in Vienna. She seeks restitution for the theft of Gretl's portrait-poignant in the context of the play because she used the sittings for Klimt as an excuse to meet with the gentile officer Fritz, which results in Hermann's desperate ploy to save his business by arguing that his son Jacob is $100 \%$ non-Jewish. Enter fictional Leo who begins the grief work on his phantom pain much earlier than the real Tom Stoppard.

\section{Conclusions}

Sketching the transition from Rock'n'Roll to Leopoldstadt, we can conclude that Stoppard's view of England as the land of blissful refuge that provided him with the "charmed life" of a successful playwright, knighted and invited to dine with royalty, rich, and fashionable with the cultural establishment, married to banking heiress Sabrina Guinness, and friends with celebrities from Mick Jagger to the late Vaclav Havel, has begun to darken. Stoppard's embrace of his new identity may be only phrased as paradox: an intensified Englishness prompted by not being English. Ultimately, however, engaging more fully with his European family roots may have led Stoppard towards a somewhat bleaker view of his English home, while he still seems to avoid a more direct and critical engagement with the culture that provided him with a new identity as a child refugee. His obsession with doubleness is evident and has long been noted (Nadel 2002): from the comic double in Rosencrantz and Guildenstern Are Dead, via the old/young dichotomies of Carr in Travesties Carr, or Housman in The Invention of Love, the secret lives of his characters or the Cold-War dichotomies of the totalitarian East and the "democratic" West, the binaries of humanities and science, abstract mathematics and concrete emotion, aestheticist art and political intervention. This essay suggests that his turn towards emotionalism, the increasingly elegiac obsession with doubles, unrequited lives, and memory are linked to a set of biographical turning points: the death of his mother and the investigation into his Czech-Jewish family roots, which laid bare the foundations of the Stoppardian art. Both Rock' $n^{\prime}$ Roll and Leopoldstadt are faux biographical plays, in which characters experience the communist and fascist regimes that Stoppard himself has escaped, while Max in Rock' $n^{\prime}$ Roll and Leo in Leopoldstadt remain British-based outsiders. Stoppard's long-standing friendship with Václav Havel and the rediscovery of his Czech roots paved the way for engaging with his own biography in Rock'n'Roll and Leopoldstadt, which gave his work a new autobiographical dimension. Stoppard's work in the 21st century is to a much greater extent than before devoted to exploring his kith and kin, and his personal history as reflecting the vagaries of European history in the 20th century.

Funding: This research received no external funding.

Institutional Review Board Statement: Not applicable.

Informed Consent Statement: Not applicable.

Data Availability Statement: Not applicable.

Conflicts of Interest: The author declares no conflict of interest.

\section{References}

Akbar, Arifa. 2020. Leopoldstadt Review—Stoppard's Family Portrait Is an Elegiac Epic. The Guardian, February 12.

Barthes, Roland. 1981. Camera Lucida. New York: Hill and Wang. First published 1980.

Behlau-Dengler, Ulrike. 2011. Zakhor!: Remembering the British-Jewish Experience in British-Jewish Drama after 1945. Trier: WVT.

Billington, Michael. 2007. Harold Pinter. London: Faber and Faber.

Brantley, Ben. 2020. Review: In 'Leopoldstadt,' Tom Stoppard Reckons with His Jewish Roots. The New York Times, February 12. 
Dawson, John W., Jr. 2002. Max Dehn, Kurt Gödel and the Trans-Siberian Escape Route. Notes of the AMS 49: 1068-75.

Gabrielatos, Costas, and Paul Baker. 2008. Constructions of Refugees and Asylum Seekers in the UK Press, 1969-2005. Journal of English Linguistics 36: 5-38. [CrossRef]

Gussow, Mel. 1995. Conversations with Stoppard. New York: Limelight.

Kelly, Katherine. 2001. Introduction. In The Cambridge Companion to Tom Stoppard. Edited by Katherine Kelly. Cambridge Companions to Literature. Cambridge: Cambridge University Press, pp. 10-22.

Lassner, Phyllis. 2014. 'Dramatizing Britain's Holocaust Memory'. In Jewish Women Writers in Britain. Edited by Nadia Valman. Detroit: Wayne State University Press, pp. 74-191.

Lee, Hermione. 2020. Tom Stoppard. A Life. London: Faber and Faber.

Leigh, Mike. 2006. Two Thousand Years. London: Faber.

Lichtig, Toby. 2020. Stump Speeches. Tom Stoppard's Family Reckoning. Times Literary Supplement, February 28.

Luckhurst, Mary. 2000. 'The Case of Theresa: Guernsey, The Holocaust and Theatre Censorship in the 1990s'. In Jewish Themes in English and Polish Culture. Edited by Irina Janicka-Swiderska and Jerzy Jarniewicz. Łódź: Wydawnictwo Uniwersytetu Łódzkiego, pp. 138-48.

Mulvey, Gareth. 2010. When Policy Creates Politics: The Problematizing of Immigration and the Consequences for Refugee Integration in the UK. Journal of Refugee Studies 23: 437-62. [CrossRef]

Nadel, Ira. 2002. Double Act: A Life of Tom Stoppard. London: Methuen.

Nathan, John. 2020. Tom Stoppard on Leopoldstadt: 'I Think about the Holocaust, It Feels Like Every Day'. The Jewish Chronicle, January 23.

Pilný, Ondřej. 2012. Pop Music and Politics in Drama: Stewart Parker and Tom Stoppard. Moravian Journal of Literature and Film 3: 63-72.

Plunka, Gene A. 2009. Holocaust Drama. The Theatre of Atrocity. Cambridge: Cambridge University Press.

Rabey, David Ian. 1986. British and Irish Political Drama in the Twentieth Century. Implicating the Audience. Basingstoke: Macmillan.

Richardson, Brian. 2001. Voice and Narration in Postmodern Drama. New Literary History 32: 681-94. Available online: www.jstor.org/ stable/20057683 (accessed on 7 March 2021). [CrossRef]

Stoppard, Tim. 2006. Rock'n'Roll. London: Faber and Faber.

Stoppard, Tom. 2020. Leopoldstadt. London: Faber and Faber.

Turner, Stuart. 2015. Refugee blues: A UK and European perspective. European Journal of Psychotraumatology 6: 29328. [CrossRef] [PubMed]

Walker, Tim. 2006. In Praise of the Patriotic Playwright. The Spectator, June 14.

White, Nicholas J. 1999. In the Absence of Memory?: Jewish Fate and Dramatic Representation; Production and Critical Reception of Holocaust Drama on the London Stage 1945-1989. Ph.D. thesis, University London, London, UK.

Whyte, Sally. 2003. Arnold Wesker. In Jewish Writers of the Twentieth Century. Edited by Sorrel Kerbel. New York: Fitzroy Dearborn, pp. 1146-49. 